\title{
ECONOMIC AND ENERGY EFFICIENCY DIAZOBACTERIN AND MINERAL FER-TILIZERS APPLICATION IN GROWING TECHNOLOGY OF WINTER RYE
}

\author{
I. G. Chuchvaha, Yu. M. Khalep
}

Winter rye is a traditional culture of Woodlands. The production uses grain, grain waste and straw. Rye grain contains $18 \%$ of protein. On poor sod-podzolic soils of Woodlands fertilization significantly increases crop yield. However, due to high price for fertilizers and low price for grain, rye is rarely economically attractive for agricultural producers.

An alternative measure for increasing winter rye yield is the use of microbial preparations. It is recommended to use Diazobacterin based on Azospirillum brazilense 18-2 (TU U 24.1-00497360002:2005) in the technology of winter rye growing. On the one hand, biological preparation provides the plant with additional nitrogen (fixed from the atmosphere), on the other hand - promotes increasing of the coefficients of active ingredient consumption from fertilizers.

In market conditions one of the main criteria for the usefulness of certain agricultural practices (application of mineral fertilizers, treatment with biological preparation etc.) is their economic efficiency. In this connection it is necessary to study the economic results of different doses of mineral fertilizers in combination with Diazobacterin in the technology of winter rye growing.

Materials and methods. The basis of the calculations is formed by average yields of winter rye of Synthetics 38 variety under the influence of fertilization and inoculation with Diazobacterin obtained in field experiments on sod-podzolic soils of the Institute of Agricultural Microbiology and Agroindustrial Manufacture of NAAS. Methods based on the traditional approach of comparing the results of certain agricultural practice with the expenses related to it were accepted as the methodological basis for the calculations of economic efficiency.

During the simulation of expenditure side technological operations and resource consumption were accepted according to the standards adopted by the NSC "Institute for
Agricultural Economics of NAAS" $[7 ; 8]$ with corresponding adjustment of operations (according to technology) and inclusion of additional direct and overhead costs associated with the use of microbial preparation.

The determination of the impact of factors on economic efficiency was performed using the method of factor deterministic analysis.

To determine the quantitative impact of factors changing on the deviation of the cost of 1 ton of grain the following two-factor deterministic model was used:

$$
C=\frac{B}{\mathrm{y}}
$$

where $\mathrm{C}$ - cost of 1 ton of grain, UAH; $\mathrm{UAH}$;

B - money outlay per 1 ha of sowing,

$\mathrm{y}$ - grain yield, $\mathrm{t} / \mathrm{ha}$.

To determine the quantitative impact of factors on the deviation of the amount of profit per 1 ha of crops the following threefactor deterministic model was used:

$$
\Pi=Ц \times \mathrm{y}-\mathrm{B},
$$

where $\Pi$ - profit from 1 hectare of sowing, $\mathrm{UAH}$;

$Ц-$ sales price of 1 ton of grain, UAH; $\mathrm{y}$ - grain yield, $\mathrm{t} / \mathrm{ha}$;

B - money outlay per 1 ha of sowing, UAH.

To determine their quantitative effect on the deviation of profitability level the traditional economic model of profitability $(\mathrm{P}$ $=\Pi: \mathrm{B} \times 100 \%)$ was transformed to the form suitable for the separation of influence of investigated factors:

$\mathrm{P}=\frac{\Pi}{\mathrm{B}} \times 100=\frac{Ц \times \mathrm{y}-\mathrm{B}}{\mathrm{B}} \times 100=\left(\frac{Ц \times \mathrm{y}}{\mathrm{B}}-1\right) \times 100$, 
where $\mathrm{P}$ - profitability level, \%;

$\Pi$ - profit from 1 hectare of sowing, $\mathrm{UAH}$;

B - money outlay per 1 ha of sowing, $\mathrm{UAH}$;

$Ц$ - sales price of 1 ton of grain, UAH;

$\mathrm{y}$ - grain yield, $\mathrm{t} / \mathrm{ha}$;

The determination of energy efficiency evaluation was carried out according to the relevant methods $[2 ; 6]$. For that, technological operations (working time of machinery and tools) and resources consumption (which were used for the economic evaluation) were transformed into energy equivalents by us.

So, the use of large doses of mineral fertilizers to ensure high yield of winter rye on sod-podzolic soils is not repaid by additional products at low prices for grain. Only if mineral fertilization is completed with Diazobacterin inoculation it is possible to provide production profitability. It should be noted that most economically and energetically feasible is the combination of fertilization with mineral fertilizers in the dose of $\mathrm{N}_{60} \mathrm{~K}_{40}$ and application of Diazobacterin. 